\title{
The Component Of Lesson Plan On Classroom Management
}

\author{
Firnando Sabetra ${ }^{1}$, Ambiyar $^{2)}$, Ishak Aziz ${ }^{3)}$ \\ 1) Program Studi Doktor Ilmu Pendidikan Pascasarjana Universitas Negeri Padang
}

2,3) Universitas Negeri Padang

*Coresponding Author

Email : firnandosabetra@gmail.com

\begin{abstract}
The present study has been conducted to identify and understand the component of the lesson plan on classroom management. The method used in this study uses a library method or approach (library research). Data obtained through observation and literature study. The results showed that the lesson plan as a well-organized planning of a lesson for estimating or projecting what will be done with the students in learning during classroom activities. The lesson plan must consist of ten components. These components of a lesson plan are: identity of school class, identity of the lesson, core competence, basic competences and indicators of competent achievement, objectives, materials, methods of teaching, media and resources, teaching activities and assessments. Planning lessons and setting goals from the begging would help the students to gather their thoughts about the lesson before class. So, the teacher should know how to manage the classroom. The classroom management is the relation between the teacher's ability and student's behavior to establish an appropriate classroom learning and teaching.
\end{abstract}

Keywords: The Component of Lesson Plan, Classroom Management.

\section{INTRODUCTION}

Educating means to help students change the importance of reading, identify parts of speech in a sentence, use the scientific method, or write cohesive paragraphs, they have helped students become educated. Seeing education as a process of helping students change leads to fundamental questions that all teachers must ask themselves. Education is the process of fostering these important and desired changes in students. It is important to point out, however, that there is debate about the extent to which education should be understood solely as a preplanned process of changing student behavior. Some educators believe that unless students are involved in creating their own educational program, educators can become preoccupied with narrow outcomes. These educators suggest that it is important for teachers to build on students' previous experiences and to look for some, not necessarily, outcomes of instruction. Although the extent to which students' educational interests and desires help determine learning outcomes, the main function of education is to help students to change in the desired way.

The formation of quality human beings as the goal of education cannot be separated from the learning process. This is because the essence of the educational process is learning. Learning refers to everything activities that directly affect the student's learning process and learning must produce learning. To achieve the goal education, it is necessary to be active in the learning process. Activity in the learning process can be described as a balance of activity between the teacher and the students. One of the efforts to increase the activity the learning process among other teachers must make the best possible planning.

The curriculum describes the skills, appearance, knowledge, and attitudes that students are expected to learn in school. The curriculum contains a statement about the student's desired 
learning and a description of the material that will be used to help students achieve this learning.

Planning depends on the context in which teaching takes place and must take into account characteristics of the class that the teacher controls for examples are classroom setting, teaching methods, or grading strategies.

Lesson plan is an activity that projects what actions will be carried out in a lesson, by coordinating the teaching components, so that the direction of objectives, materials, methods and techniques as well as evaluation becomes clear and systematic. Lesson plan is what teachers and children will do in the classroom and outside the classroom. Lesson plan activity is a projection of what is needed in order to achieve valuable goals. Lesson plan programs includes activities to formulate learning objectives, formulate content / subject matter to be studied, formulate learning activities and formulate learning resources or learning media to be used and formulate assessments learning outcomes.

The function of lesson plan is as a guide for teacher activities in teaching and guiding children in learning activities that are arranged systematically and systemically. Lesson plan programs must be based on a systems approach that prioritizes integration between objectives, materials, learning activities and assessments.

\section{RESEARCH METHODS}

This research method is a literature study research or commonly referred to as a literature study (library research). Literature study research according to Mestika Zed (2014) has the main characteristic, namely that researchers deal directly with available sources. In this article, sources are taken in the form of articles from journals that have been accredited by Sinta and journals that have been indexed by Scopus. The sources used by researchers are "ready to use" which means that researchers do not research in the field, only deal directly with available source materials (Mestika Zed, 2014). The analysis technique used in this research is the content analysis technique

\section{RESULTS AND DISCUSSION}

\section{Definition of a Lesson Plan}

A lesson plan is a plan for teaching lesson(s) developed by a teacher based on the curriculum in order to meet specific curriculum goals. Mulyasa (2011) says that a lesson plan is a plan which describes procedures and management of study in order to reach one or more basic competencies regulated in the Standard of Content and extended in the syllabus. Moreover, Hosnan (2014) has defined a lesson plan as a plan for teaching-learning developed by the teacher based on the syllabus for one meeting or more in order to achieve basic competencies.

Lesson plans play an important role in teaching-learning processes. Richards and Bohlke (2011) have written, ".. planning a lesson before teaching is considered essential in order to teach an effective lesson." By preparing a lesson plan, it will be easier for the teacher to achieve her goals for the course. With a lesson plan, a teacher is better able to manage her time, efforts and resources in order to conduct effective teaching-learning activities to achieve her objectives for the lessons. Harmer (2007) states that lesson plan as teaching preparation which developed based on teachers' view about the proper process for students' and curriculum expectations. It is explained that the lesson plan is a teaching-learning process developed by the teacher based on the students' needs through the observation and related to the point of the 
curriculum. If a teacher does not examine the students' need, interest, ability, students' learning style, and curriculums' goals, it is ensured that the originating of the lesson plan is not effectively works. Brown (2001) said that the term lesson plan is considered as an organized set of activities which contain several elements and cover a period of classroom time. Lesson plan usually contains some components, such as goals, objective, indicators, materials and equipments, procedure, learning source, evaluation and extra class work.

The lesson plan is the lowest or most specific level of instructional plans. It is derived from the analysis of the scheme of work / unit plan. Thus, when the unit plan is broken down into smaller topics and sub-topics, we have the lesson topics, which can be used to plan a lesson (Okai, 2010). A lesson plan could therefore, be described as a planned organized amount of subject -matter and learning experiences that the teacher will communicate to the learners with details of how instruction will take place within a lesson period. Lesson planning is an important activity for a teacher. Taruvinga and Moyo (2000) observe that a lesson plan supplies guidance and feelings of confidence to the teacher in the art of teaching. If lessons are well or pre-planned, both learning and teaching becomes simplified. According to Okai, lesson plan is useful for the following reasons: the teacher follows correct steps and procedures in teaching; time is not wasted in the class since the period of one lesson must be used to cover the day's lesson topic; meaningful objectives are pursued in the lesson; activities are related to the content and objective; instructional materials are adequately selected and utilized; proper evaluation procedures and tools are used; a substitute teacher can use the lesson plan to hold on the class; and the most important content is identified for learner.

A lesson plan, therefore, could also be defined as a well-organized planning of a lesson for estimating or projecting what will be done with the students in learning during classroom activities (Musingafi, Mhute, Zebron, \& Kaseke, 2015).

Teachers are occupied with a set of written steps about what they are going to do in the classroom called lesson plan. Brown (2001:149) describes lesson plan as "a set of activities which "represent 'steps' along a curriculum before which and after which have a hiatus (a day or more) in which to evaluate and prepare for the next lesson". Additionally, Woodward (2001) states that lesson planning is not only in a written form, it can be defined as everything a teacher does when s/he is thinking of the next lesson such as visualizing, reading resources, or eve staring at the ceiling. Harmer (2007) highlights two. Firstly, lesson plan is guide for teachers to refer to. Creative changes may be done to adapt with what actually happens in the classroom but in the end lesson plan is still a guide for teachers to fall back on. Secondly, it relates to teacher's relationship with students. Teacher who has done planning beforehand suggests their commitment toward teaching and will get positive respond from students.

According to Curriculum Document 2013,one of the factors that can lead to the success of curriculum implementation isthe compatibility of human resources in this case the teachers. The latter is in line with Dermody (2004) who states that the success of Theme-Based teaching relies onthe role of teachers and their knowledge as well as competencies. In order to provide an effective lesson that is based on Theme-based teaching, every activity in classroom has to be arranged in a purposeful way.This makes lesson planning a fundamental stage in teachinglearning cycle.

Combining good lesson planning and Theme-based teaching can initiate effective instruction. The lesson plan is explained as the procedure and management of study to achieve one and more basic competence which is regulated in standard competence and enlarged in the syllabus. It can be assumed that there are several activities and organizations developed by the teacher in a plan of course to achieve based competency appropriate in the curriculum. 


\section{Lesson Plan Components}

Before starting to design the lesson plan, it is important for the teacher to understand the components that consist in the lesson plan. The components help teacher in constructing the lesson plan effectively and can achieve the teaching and learning goal. Dick and Riser as cited in Bidaria (2013) explain that there are six components in lesson plan; indicators, objectives, activities, material, instructional media, and assessment. Specifically, as determined by the Decree of the Minister of Education No. 103 (2014) the lesson plan components of the 2013 Curriculum, are: identification of subjects, core competence, basic competence, competence of indicator achievement, learning materials, steps in learning activities, assessments, remedial work, enrichment activities, teaching-learning media, instruments and learning resources. Lesson study does provide a bridge for the gap between knowledge acquired by teachers about teaching and the actual implementation of that knowledge in the classroom.

There are some steps and organization that must be done by the teacher to develop her lesson plan such as establishing the teaching activities, the time, the place, the materials, the media to be used, etc.

Wajnryb (1992) has stated that a lesson plan begins with a list of objectives, and works its way through a number of procedures, steps and phases to the end result, the finished plan.

In the 2013 Curriculum, lesson plans have to be made clearly and systematically, so that the teaching-learning process will be interactive, inspiring, fun, and challenging. According to the Ministry of Education and Culture Decree Number 22 of 2016 about Standards for Processing, each lesson plan must consist of ten components. These components of a lesson plan are:

1. Identity of school class, which consists of the name of the institution, the unit, the class and the semester.

2. Identity of the lesson, which consists of the name of the subject, the number and topic of the lesson and the date and time allocated.

3. Core competence, which describes the main competence that students need to learn for the school level class in that subject in the aspect of attitudes, knowledge, and skills.

4. Basic competences and indicators of competent achievement. Basic competences are several competences which have to be mastered by students of a certain subject as a basis for establishing an indicator of competence. Meanwhile, indicators of competent achievement are behaviors or performances which can be measured and observed to show the achievement of certain basic competences.

5. Objectives, which can be defined as processes and products of learning expected to be achieved by learners in the process of teaching-learning based on the core competence and basic competences.

6. Materials, which consist of relevant theories, facts, principles, and procedures which are written based on the indicators for achievement of competence.

7. Method(s) of teaching is the method(s) used by a teacher in order to create teachinglearning processes. Some methods for teaching that can be used in teaching speaking ESL are the Communicative Language Teaching (Communicative) Approach and the Cooperative Language Learning Approach/Method.

8. Media and resources. Media are used by the teacher to deliver materials and maintain the processes, such as books, slides, overheads, flash cards, tape recordings, CDs and VCDs and the Internet. Materials can be taken from various sources, such as authentic materials from libraries and the internet including textbooks, novels, English newspapers and magazines and other IT resources.

9. Teaching activities, which are divided into three stages, namely pre-teaching, whileteaching and post-teaching activities. 
10. Assessments, which are done to evaluate the results of the students study in which the instruments used are based on the indicators for achievement of competency previously determined.

The format of a lesson plan is largely determined by the purpose of the lesson. The detailed format of a lesson plan is not something that can be determined by someone who is not familiar with the classroom and teaching style. These are: a) Educational objectives-also called "targets" by some: Description of the things students are to learn from instruction: what students should be able to do after instruction (e.g., the students can write a summary of a story, the students can differentiate adverbs from adjectives in a given passage). B) Materials: Description of the resources, materials, and apparatus needed to carry out the lesson, teaching activities and strategies: Description of the things that will take place during instruction; often includes factors such as determining student readiness, identifying how the lesson will start, reviewing prior lessons,providing advanced organizers, identifying specific instructional techniques to be used (e.g., discussion, lecture, silent reading, demonstrations, seatwork, game, cooperative activities) specifying the sequence of techniques, providing students practice, and ending the lesson, and c) Assessment: Description of how student learning from the lesson will be assessed (e.g., homework assignment, oral questions, essay).

\section{Classroom Management}

Education is crucial to the social, political and economic development of any nation and consequently effective education is very important. Effective teaching is important because it is based on helping children developments from one level to another in a friendlier interactive society and to help students to be independent. Effectiveness does not mean being perfect or giving excellent performances, it is mean being able to plan effective lessons to catch the learner's attention and to get them wholly engaged within the learning process, and consequently no time is available to make noise or bad behaviors in the classroom. For that it has been said that good order is the foundation of all things (Othmane, 2015).

Classroom management is the key to success and improves the quality of learning in the classroom. Classroom management deals with how things are generally carried out in the classroom. According to Rothstein (2008) classroom management is the relation between the teacher's ability and student's behavior to establish an appropriate classroom learning and teaching. Also Groves (2009) asserted that "classroom management is set of rules, words, and deeds that, the classroom teacher, use to keep classroom running smoothly so that the teacher and the students can work, teach, and learn safely and efficiently". Classroom management involves all aspects of what is going on in the classroom while a lesson is being taught because it includes elements of classroom discipline but it focuses more on creating learning environment that is organized, engaged and respectful for both teachers and students. (Hanane, 2016).

Teachers as well were concerned with the questions of how to teach effectively and how to plan lessons successfully in order to avoid any mistakes with classroom management.

\section{CONCLUSION}

Lesson plan is the most effective skill for teachers as a detailed outline to teach. All the teachers either experienced or novice one should give more attention to develop an organized classroom environment. If teachers concentrate much more on preparing and planning lessons, it will help the learners too much in increasing their positive discipline, and this lead to create an appropriate classroom management. Throughout this research, the researcher has argued 
that teacher's lesson plan is one major aspect for creating a well-managed and organized classroom. The lesson plan must consist of ten components. These components of a lesson plan are: identity of school class, identity of the lesson, core competence, basic competences and indicators of competent achievement, objectives, materials, methods of teaching, media and resources, teaching activities and assessments. the teacher should know how to manage the classroom. The classroom management is the relation between the teacher's ability and student's behavior to establish an appropriate classroom learning and teaching. Finally, teachers should prepare and plan their lessons to create good student's and pay more attention on how planning can help them to improve an effective classroom management.

\section{REFERENCES}

Dermody, B. (2004). Improving Student Learning Through Theme Based Curriculum Design and Team Teaching: An Action Research Study. (Master Thesis, Dublin Institute of Technology, Ireland).

Groves, E.(2009). The everything classroom management book: a teacher's guide to an organized, productive, and calm classroom. United State: Adams media.

Hanane, T., (2016). The Effects of Lesson Plan on Teacher's Classroom Management; Case study: Second Year English Students of LMD at Biskra University.

Harmer, J. (2007). How to Teach English. New York: Pearson Education Limited.

Mulyasa. (2011). Kurikulum tingkat satuan pendidikan. Bandung: PT. Remaja Rosdakarya.

Okai, A.U. (2010). History methods. Lagos. National Open University of Nigeria.

Musingafi, Maxwell C. C., Mhute, Isaac, Zebron, Shupikai, \& Kaseke, Kwaedza E. (2015). Planning to Teach: Interrogating the Link among the Curricula, the Syllabi, Schemes and Lesson Plans in the Teaching Process. Journal of Education and Practice

Othmane, M,.(2015). The Role of Lesson Planning in Improving Effective Classroom Management. The Case of Middle School Teachers of English at Ahmed Zeid-Biskra.

Richards, J. C., \& Bohlke, D. (2011). Creating effective language lessons. New York: Cambridge University Press.

Michael K. Russell and Peter W. Ai rasian. (1967).Classroom Assessment: Concepts applications, 7th Edition. McGraw Hill.

Ministry of Education and Culture RI. (2013). Decree number 81a about the implementation of curriculum. Jakarta: The Ministry of Education and Culture RI.

Wajnryb, R. (1992). Classroom observation tasks: A resource book for language teachers and trainers. Cambridge: Cambridge University Press.

Woodward, T. (2004). Planning lessons and courses, United Kingdom: Cambridge university press. 